ZIBELINE INTERNATIONAL

ISSN: 2617-9415 (Online)

CODEN: ESSDAX

RESEARCH ARTICLE

\title{
A CONCEPT PAPER: THE EFFECTIVENESS OF PROJECT BASED LEARNING ON SELF- EFFICACY'S LEVEL AMONG SLOW LEARNER STUDENTS IN MALAYSIA
}

\author{
Nurul Farhana Binti Zainudin*, Zakiah Binti Mohamad Ashari, Azlina Binti Kosnin \\ Faculty of Science Social and Humanities, Universiti Teknologi Malaysia, Malaysia \\ *Corresponding Author Email: nfarhana265@graduate.utm.my
}

This is an open access article distributed under the Creative Commons Attribution License, which permits unrestricted use, distribution, and reproduction in any medium, provided the original work is properly cited

\section{ARTICLE DETAILS}

\section{Article History:}

Received 01 April 2019

Accepted 30 May 2019

Available online 10 June 2019

\section{ABSTRACT}

The number of students with learning disability keep increasing every year. Slow learner student is a student with learning disability that has a mental age lower that their actual age. Due to their weakness, they always have low level of self-efficacy which is a confidence in themselves to complete a task given. Therefore, the researcher decided to conduct this study to improve the level of self-efficacy among slow learner students in Malaysia. This study will use Pre and Post Quasi-Experimental research design. The purposive sampling technique will be use and choose 30 slow learner students in primary school. The instrument that will be used is Project Based-Learning Module and Academic Self-Efficacy Scale by Zimmerman, Bandura and Martinez-Pons (1992) which consists of 11 statements and seven likertscale. The data will be analysed using T-test by SPSS. The expected result for this study is the students in experimental group will have higher level of self-efficacy compare to controlled group and there are increasing number of self-efficacy's level after treatment. The implication of this study is it helps slow learner students in improving their self-efficacy and this study also provide alternative teaching method to the slow learner students instead traditional teaching method.

\section{KEYWORDS}

Self-Efficacy, Project Based Learning, Slow Learner

\section{INTRODUCTION}

Nowadays, the number of learning disability student is increasing from year to year. Based on special education data from the Ministry of Education, Malaysia, a total number of 34536 learning disability student were enrolled into Integrated Special Education Program (PPKI) compared to 2016 with 32576 registered [1]. Learning disability students were included in the category of special needs students which are those with cognitive problems considered to be taught and can benefit from formal education [2]

Learning disabilities are consists of Down Syndrome, Mild Autism, Attention Deficit Hyperactivity Disorder (ADHD), Minimum Retardation and Specific Learning Disability. Slow Learner are students who are included in the category of problematic learners. According to a researcher, slow learner students refer to students with a mental age level less than their physical level. For example, the students are 12 years old but their mental age is only nine years old [3]. Therefore, slow learner students are likely to have problems in computation, writing and reading. Self-efficacy is a concept from social cognitive theory about a belief of oneself in completing a task [4]. Slow learner students have low efficacy levels especially during the learning process. This is because of their under-developed mental state; they feel unable to do a complicated task. This is supported by the study of a researcher that learning problematic students have low self-efficacy compared to those students who have no learning problems and slow learner students are also included in this category [5]. When the self-efficacy of the student is low, it indirectly affects the outcome of the learning process of the students.
The appropriate learning strategy plays an important role in the learning outcomes of the pupil in terms of cognitive or affective. Project-based learning model is an appropriate teaching strategy to use for slow learner students. This is because, project-based learning $(\mathrm{PjBL})$ is a learning model that uses co-operative learning methods with teachers or peers in solving real-world problems. Teacher will act as a facilitator and assist the students in completing the task collaboratively with their peers. This strategy gives full freedom to students in solving problems and assignments collaboratively. Therefore, this learning strategy will help the students in enhancing or improving their self-efficacy in themselves. In conclusion, slow learner students is also known as learner with disability that have slow progress in learning and completing the task. Due of that, they always have low self-efficacy and avoid completing the task given. Therefore, the researcher will be conducted this study to help the slow learner students in improving the levels of self-efficacy in themselves by implementing project-based learning module in their learning process.

\section{LITERATURE REVIEW}

\subsection{Project-Based Learning}

Project based learning is a well-known and widely used of instructional strategy on students learning process [6]. It is an innovational learning strategy that created independent thinkers and learners [7]. Project based learning is a student-centered learning with dynamic classroom approach where the students gains a deeper knowledge through the exploration of real-world problem. There are seven essentials elements in project-based learning based on Figure 1 below 


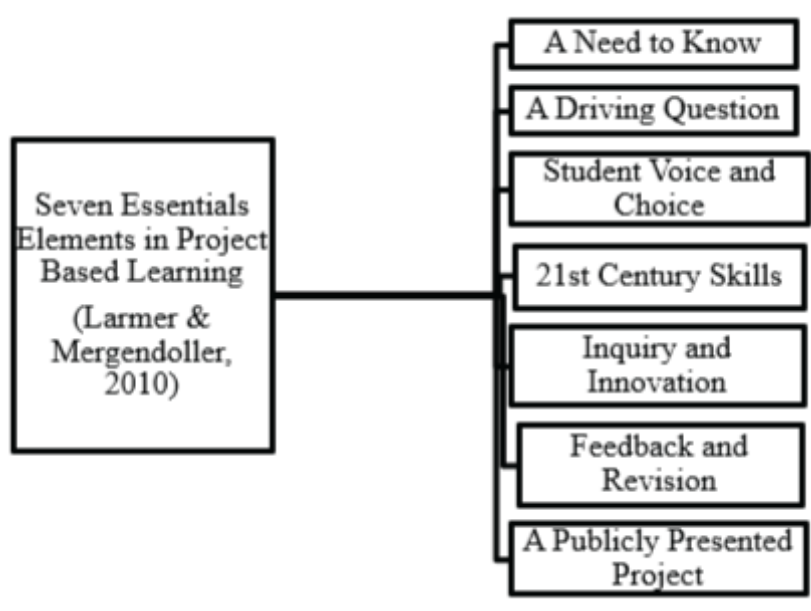

Figure 1: Seven Essentials Elements in Project Based Learning

According to a study there are seven elements in project-based learning [8]. First is a need to know where the students will be explained by the teacher about the topic they will be studied through discussion. Second is a driving question where the students will do a brainstorming about the topic and find out the solution regarding that topic while the teacher ask the question about the topic. Third is student voice and choice where the students will choose the solutions for the questions before and the teacher will supervise the students' choice. Forth is $21^{\text {st }}$ century skills which the students will use the $21^{\text {st }}$ century skills such as communication, collaboration and critical thinking to solve the question. Fifth is inquiry and innovation which the students will ask more details question for inquiry and do an innovation to search for the answer. Sixth is feedback and revision where the students will give a feedback about the topic they have been investigated and make a revision about the topic. Lastly is a publicly presented project where all the students will present their project to the teacher and peers. Therefore, these are seven elements that should be included inside the project-based learning module.

A study by a previous researcher investigate how project-based learning can improve intrinsic motivation components which are interest, academic efficacy and cognitive engagement towards students [9]. They found out that project-based learning mostly effect on students' interest in learning. A researcher also conducted a study using project-based learning on students' academic achievement [10]. The result from their study showed that project-based learning is efficient and give good impact on students' academic achievement.

\subsection{Self-Efficacy}

Self-efficacy is one of important element in every human being. According to a scholar, self-efficacy is the belief of oneself about the capabilities in doing certain task and completing challenging task [11]. Self-efficacy theory is a theory lies on the centre of social-cognitive theory which is theory about how cognition plays an important role in every human behaviours and actions [12]. Based on Figure 2 the originator of theory, a scholar names four sources of self-efficacy which are mastery experience, vicarious experience, verbal persuasion and, emotional and physiological states [13].

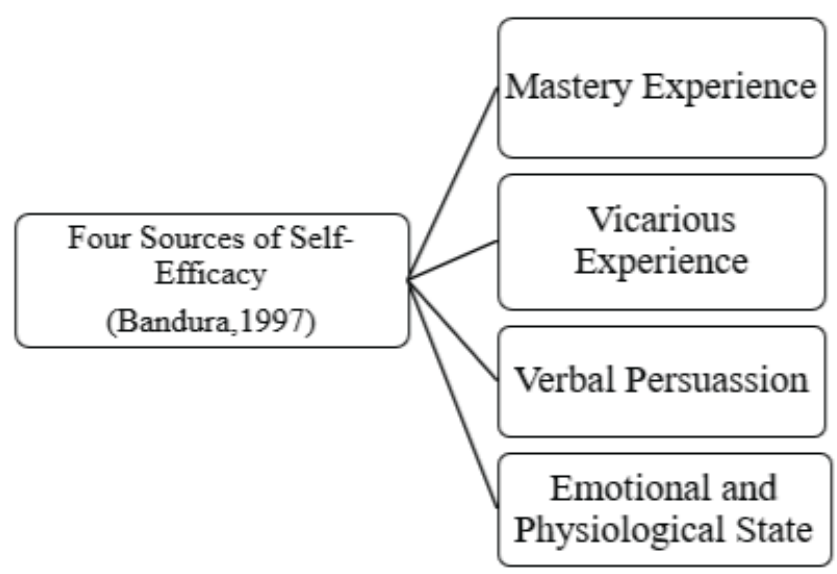

Figure 2: Sources of Self-Efficacy

Mastery experience is a personal or direct experience gain to increase self-efficacy and the most reliable source of self-efficacy [14]. For example, the students experience success in accomplish the task given can increase their self-efficacy. Second is vicarious experience which comes from the observation of people around especially someone who considered as a role model [15]. For example, the students observe their peers in completing the task so they feel they also can accomplish that particular task too. Third is verbal persuasion which is influential or encouragement from close people around in believing the capabilities in completing or doing that task [16]. For example, the encouragement from parents and teachers for the students accomplish the task given can increase their self-efficacy. Last source of self-efficacy is emotional and physiological states. If the students emotional and physiological is in good state, it will also influence their self-efficacy to be in a good state.

There are many past researches shown that students with learning disability including slow learner has low level of self-efficacy. The study on 34 primary school students by a researcher found that children with learning disability has low expectations as well as self-efficacy beliefs in themselves compared to students without learning disabilities. Besides that, the study by a recent scholar on college students also stated that students with learning disability has low level of self-efficacy [17]. In addition, a study on learning disability students by another researcher indicated that students with learning disabilities had lower levels of perceived self-efficacy [18].

Therefore, based on these past researches it can be seen that students with learning disabilities has low level of self-efficacy which can affect their learning process. Hence, the researcher sees a need for this research and propose to conduct this study to improve the level of self-efficacy among slow learner student so that their self-efficacy will become better.

\section{OBJECTIVE}

There are two objectives in this study which are:

- To investigate the differences of self-efficacy's level before and after the implementation of project-based learning module in teaching.

- To investigate the differences of self-efficacy's level between experimental and controlled group after the implementation of project-based learning module in teaching. 


\section{HYPOTHESES}

There are two hypotheses for this study which are:

$\mathrm{H}_{0}$ There are no significance differences of self-efficacy's level before and after the implementation of project-based learning module in teaching.

$\mathrm{H}_{0}$ There are no significance differences of self-efficacy's level between experimental and controlled group after the implementation of projectbased learning module in teaching.

\section{METHODOLOGY}

This study will use pre and post quasi-experimental study research design. In the experimental group is a group of slow learner students with treatment while in controlled group is a group of slow learner students without treatment. The variables for this study are project-based learning module as an independent variable and dependent variable is self-efficacy. The design is as follows:

Table 1: Experimental Group

\begin{tabular}{|c|c|c|}
\hline Before & $\begin{array}{c}\text { Application of } \\
\text { Teaching using Pjbl } \\
\text { Module }\end{array}$ & After \\
\hline Self-efficacy's level & 3 Months & Self-efficacy's level \\
\hline
\end{tabular}

Table 2: Controlled Group

\begin{tabular}{|c|c|c|}
\hline Before & $\begin{array}{c}\text { Application of } \\
\text { Regular Teaching } \\
\text { Method }\end{array}$ & After \\
\hline Self-efficacy's level & 3 Months & Self-efficacy's level \\
\hline
\end{tabular}

The selected sample will be consists of 30 slow learner students in primary school in Melaka using purposive sampling technique. The students will be selected from two different primary schools. The total of students will be divided into two groups which are experimental and controlled group. The slow learner students will be diagnosed on the following basis.

- Screening

- Parental Interview

- Teacher Interview

The instruments that will be used for this study is the module developed by the researcher and one questionnaire to evaluate the students' level of self-efficacy. The questionnaire that will be used is Academic Self Efficacy Scale that have 11 statements describing the students' confidence about their academic and completing the task [19]. It uses 11 Likert scale from 1 (not sure at all) to 7 (completely confidence). The questionnaire will be simplified to match the level of the students.

Based on Figure 3, there are the procedure of this study. Firstly, the researcher will work with 30 students who will be placed into two groups. Before the experiment begin, the researcher will distribute the questionnaire to the students and give a brief explanation to all the samples and parents about this study. After that, the study will begin by the first group which is experimental group that will be taught by using a project-based learning module produce by the researcher. The duration of the treatment is for three months. The researcher will give an explanation and guidance to the teacher regarding the module implementation. Meanwhile, the second group which is controlled group will be taught using traditional method by another teacher. Both of the groups will be taught on the same period of time. After three months, the researcher will distribute again the questionnaire to evaluate the improvement of self-efficacy among slow learner students. The data will be analysed using statistical method [20].

For the data analysis, the data collected will be analysed statistically by the researcher after the experiment ended. Based on research question, the data will be analysed using T-test to study the differences of selfefficacy level before and after the treatment and also to study the differences of self-efficacy levels between two groups. The data will be presented in table form for better understanding. The software that will be used to analysed the data is Statistical Package of Social Science (SPSS) which is a well-known and established software among social science researcher. The expected results from the researcher will be explain below [21].

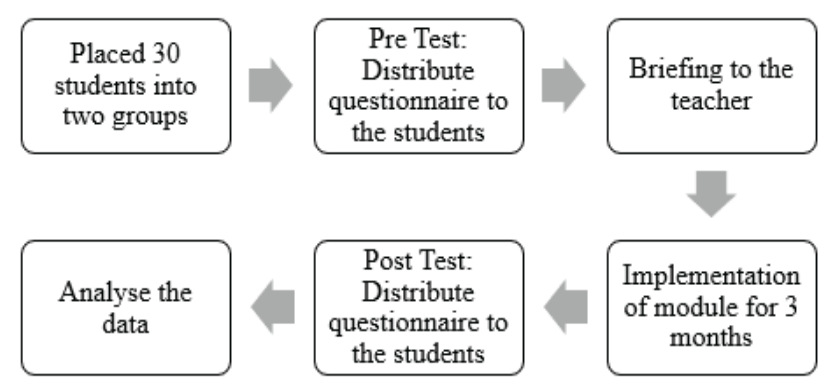

Figure 3: Procedure of study

\section{EXPECTED RESULT}

Based on research objective in Figure 4, there are two results that can be expected from this study. Research objective one on finding the difference of self-efficacy's level before and after the implementation of project-based learning in teaching, the researcher expects to have a difference before and after which the level of self-efficacy after the implementation will be higher than before the implementation.

For the research objective two which is to find the self-efficacy level between two groups the researcher expects to have a higher level of selfefficacy from experimental group compare to controlled group. This is because the experimental group are having a project-based learning being implemented in their teaching method.

Therefore, in order for this expected result to be achieve the future researcher should conduct this study carefully and precisely. In addition, the selection of teacher and sample will influence the outcome for this study.

Table 3: Expected Results based on Research Objective

\begin{tabular}{|l|l|}
\hline \multicolumn{1}{|c|}{ Research Objective } & \multicolumn{1}{c|}{ Expected Results } \\
\hline $\begin{array}{l}\text { To investigate the differences of } \\
\text { self-efficacy's level before and } \\
\text { after the implementation of } \\
\text { project-based learning module } \\
\text { in teaching. }\end{array}$ & $\begin{array}{l}\text { There are significance } \\
\text { differences of self-efficacy's } \\
\text { level before and after the } \\
\text { implementation of project- } \\
\text { based learning module in } \\
\text { teaching. }\end{array}$ \\
$\begin{array}{l}\text { To investigate the differences of } \\
\text { self-efficacy's level between } \\
\text { experimental and controlled } \\
\text { group after the implementation } \\
\begin{array}{l}\text { There are significance } \\
\text { module in teaching. }\end{array}\end{array}$ & $\begin{array}{l}\text { differences of self-efficacy's } \\
\text { implementation of project- } \\
\text { imere and after the }\end{array}$ \\
\hline
\end{tabular}

\section{LIMITATION AND RECOMMENDATION OF STUDY}

This study is focused on slow learner students in improving their level of self-efficacy. Therefore, the module is only suitable for the students with same characteristic. Hence, the results of this study cannot be generalized to another students. In addition, this study has limited number of samples which are 30 students that are minimum number required for experimental study. The small number of samples will give an effect to the statistical result. 
Therefore, for future researcher the scope of this study can be widen to another type of learning disability or combined the types of learning disability. So that, the generalization also can be widen to another characteristics. The number of samples also can be enlarged after the scope is widen. This is because the number of specific categories of learning disability is quite limited. Hence, if the category is combined it can help the researcher to have a large number of samples to conduct the study as well as the data gathered will have better result from the analysis.

\section{CONCLUSION}

In conclusion, this study will be conducted in concern of self-efficacy's level among slow learner students. The researcher aims to improve the level of self-efficacy among slow learner students because of their low level of self -efficacy. The implication of this study is the researcher hope that the module can be used by another teacher to another slow learner student to improve their level of self-efficacy. This study also can be an aid to the teaching method in class instead of using traditional teaching method the teacher can use alternative technique which is project-based learning teaching method. Although slow learner is categorized as learning disability students, they also a student that need concern as another normal student.

\section{REFERENCES}

[1] Kementerian Pendidikan Malaysia. 2017. Data Pendidikan Khas 2017.

[2] Kementerian Pendidikan Malaysia. 2016. Data Pendidikan Khas 2016

[3] Kementerian Pendidikan Malaysia. 2017). Perangkaan Pendidikan Malaysia.

[4] Roslina, P., Wahid, A. 2017. Gaya Pembelajaran Kanak-Kanak Lembam, 323-348.

[5] Yusuf, M. 2012. The impact of self-efficacy, achievement motivation, and self- regulated learning strategies on students' academic achievement. Proc Soc Behav Science.

[6] Seyed, S., Salmani, M., Motahari Nezhad, F., Noruzi, R. 2017. SelfEfficacy, Achievement Motivation, and Academic Progress of Students with Learning Disabilities: A Comparison with Typical Students. Middle East Journal of Rehabilitation and Health, 4(2).

[7] Hung, C., Hwang, G., Huang, I. 2012. A Project-based Digital Storytelling Approach for Improving Students' Learning Motivation, Problem-Solving Competence and Learning, 15, 368-379.

[8] Bell, S. 2010. Project-Based Learning for the 21st Century: Skills for the Future. The Clearing House, 83(1), 39-43.
[9] Larmer, J., Mergendoller, J., Boss, S. 2015. Setting the standard for project-based learning: A proven approach to rigorous classroom instruction. Alexandria, VA: Association for Supervision and Curriculum Development.

[10] Ocak, M., Uluyol, C. 2010. Investigation of college students' intrinsic motivation in project-based learning. International Journal of Human Sciences, 7(1), 11 52-1169.

[11] Panasan, M., Nuangchalerm, P. 2010. Learning Outcomes of Project-Based and Inquiry-Based Learning Activities. Journal of Social Sciences, 6(2), 252-255.

[12] Bandura, A. 1994. Self-efficacy. In V.S. Ramachaudran (Ed.), Encyclopedia of human behavior (Vol. 4, pp. 71-81). New York: Academic Press. (Reprinted in H. Friedman [Ed.], Encyclopedia of mental health. San Diego: Academic Press, 1998).

[13] Bandura, A. 2001. Social cognitive theory: An agenetic perspective. Annual Review of Psychology, 52(1), 1-26.

[14] Bandura, A. 1977. Towards a Unifying Theory of Behavioral Change. Psychological Review, 84(22), 191-215.

[15] Schunk, D.H., Usher, E.L. 2012. Social cognitive theory and motivation. In R. M. Ryan (Ed.), The Oxford handbook of human motivation (pp. 13-27). New York, NY: Oxford University Press.

[16] Bandura, A. 2012. On the functional properties of perceived selfefficacy revisited. Journal of Management.

[17] Bandura, A. 1997. Self-efficacy: The exercise of control. New York, NY: Freeman.

[18] Bandura, A. 1982. Self-efficacy mechanism in human agency". American Psychologist. 37(2): 122-147.

[19] Aikhomu, I.E. 2015. Learning Disability Status and Gender as Predictors of Self-Efficacy. ProQuest Dissertations and Theses, 155. Retrieved

https://vpn.utm.my/docview $/ 1656466467$ ?accountid=41678

[20] Ben-naim, S., Laslo-roth, R., Einav, M., Biran, H., Margalit, M. 2017. Academic self-efficacy, sense of coherence, hope and tiredness among college students with learning disabilities. European Journal of Special Needs Education, 32(1), 18-34. https://doi.org/10.1080/08856257.2016.1254973

[21] Zimmerman, B.J., Bandura, A., Martinez-Pons, M. 1992. Selfmotivation for Academic Attainment: The Role of Self-efficacy Beliefs and Personal Goal Setting. American Educational Research Journal 29: 663676.

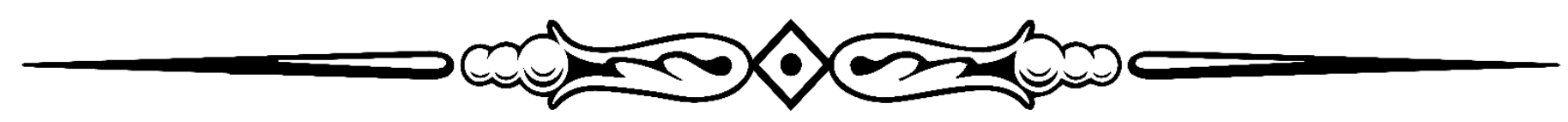

